\title{
TRIBAL DISPOSSESSION \\ THROUGH LAND ACQUISITION: A STUDY OF OPEN CAST MINES IN WEST BENGAL
}

Sreenita Mondal*

\begin{abstract}
Since Independence the State-led development strategies like hydro-electric projects, dam constructions, mining projects have displaced and dispossessed a large number of tribals and economically marginalised rural population through the dreadful Land Acquisition Act. This gained a further momentum in the neo-liberal period. The anecdotes of tribal victimisation, continuous erosion of their rights and how they are coping in the market economy are repeatedly studied. The Raniganj coal mining region of West Bengal where few large-scale open cast mines are operational is not an exception in this regard and needs to be contextualised in a deeper socio-economic-politico context. However, this paper seeks to understand how far the deprivation of the tribals belonging to the project affected villages is integral to land acquisition.
\end{abstract}

\section{Introduction}

Constituting around 7.5 per cent of the total population of India, tribals represent the most deprived and marginalised section of the society. The tribals havetheir unique way of living. They mostly live in relative geographical isolation, they have their independent identity, more selfcontained, not driven by the market economy and reliant on natural resources. Being dependent on natural resource base in general and land in particular, tribals endure a different set of crisis when they face displacement (Dhagamwar,2011). The process of dispossession is even more complex than displacement. It is the process of extermination of certain groups both physically (by plundering of natural resources) and culturally (by the process of forced relocation and integration). By the process of dispossession, people not only lose land and property, citizenship and voice, but also the secure sense of belongingness (Butler and Athanasiou, 2013). Sanyal (Quoted by Sushmita Pati, 2016) describes dispossession as the state of destitution that transform people into a vast indistinguishable mass of 'have nots'. Dia Da Costa (2010) seeks to demonstrate the deeper political

*Assistant Professor, Department of Geography, Raniganj Girls' College, Searsole, Raniganj, Dist. Barddhaman, West Bengal, PIN: 713358.

The author offers her sincere gratitude and acknowledgement to Prof. B. S. Butola of Centre for the Study of Regional Development, Jawaharlal Nehru University for his guidance and helpful comments.

Journal of Rural Development, Vol. 36, No. 2, April - June : 2017 
meaning of dispossession by emphasising on the cultural (way of living) component of it.

There is a major lack of reliable statistics to encounter the contemporary situation of displaced and dispossessed population in India.There is so much of literature based on micro-level surveys, primarily pointing out how tribals are often caught in a double bind, when the question of dispossession appears. However, it wasfor thefirst time thatFernandesand Thakural (1989) have provided an immense volume of data on displacement.Mohammad Asif's (2000) findings supported the estimation of Fernandes. Asper hisestimation, since Independence, about 1.7 million peoplewere displaced by 119 Central and State government projects, among them more than half (around 0.9 million) were tribes. Even in the last 40 years, mining activities have alone displaced 2.1 million population including 1.4 million tribals. These varied statistics substantiated the claims that economically marginalised rural population in general and tribals in particular are clearly on the peripheries of development discourse of India.

Several scholars have the view that physical isolation from the mainstream and dependency on natural resource base are the major reasons for even more deprivation among the dispossessed tribals. But it is not always true. In some parts of India, the displaced population is deprived across class, caste and community. Tribal identity cannot be the only factor in determining the magnitude of dispossession. In neo-liberal context it can only provide a partial understanding of the position of dispossessed tribals. Mathur (2013) in his article has raised the issue of Indian law of land acquisition as a real culprit for this kind of discrimination between haves and have-nots. The additional complexities like lack of information, differential interest of the stakeholders, multiple laws with overlapping and often incongruous content, resettlement and rehabilitation (R\&R) policies with fault lines and ambiguous execution procedures generate pressure towards polarisation. Hence, discussion following a single axis would be naive as well as blemished. The enormity of dispossession through land acquisition cannot be understood until and unless they are contextualised in a deeper socio-economic-politico and legal framework. The micro level studies on the dispossessed (both tribalsand non-tribals) in India can address specific issues intensively.

\section{Objectives}

The objectives of the study are:

- To show how development through largescale projects (like open cast mining project) in the neo-liberal period needs to be understood in the context of capital accumulation, displacement, dispossession, detribalisation or social exclusion

- To find out the immediate effects of land acquisition on marginalised, poor and excluded communities. In other words, the new relations of production and how the affected population (both tribals and non-tribals) are responding to it.

- To scrutinise the complex mechanism, more specifically the dynamic policies of land acquisition for resource extraction and how these complex processes are responsible for the relative dispossession of the marginalised sections of the society. 


\section{Methodology}

This paper seeks to place tribals in a regional context in order to propose that there can be no one unilinear process in conceptualising social differences in dispossession. It tries to explore the three possibilities for the deprived condition of dispossessed tribals of coal mining area of West Bengal; is it a social issue, politico-economic issue or is it a legal issue? In fact, can the answer be an overlapping one? In otherwords, it triesto capture how far the deprivation of the tribals belonging to the project affected villages is integral to land acquisition, alternatively, are they overall part of the deprived scenario or bypassed in the process of regional development? The coal mining region of West Bengal contains a sizeable proportion of tribal population. Sonepur Bazari project, which is considered as one of the largest open cast coal mines under Eastern Coalfields Limited (ECL) is operating in this area and has not been an exception in terms of tribal dispossession. The striking feature is that this region sets an example of the relative ability of the government to accumulate land for resource extraction in a relatively peaceful manner.

The data for this study were taken from secondary sources like District Census Handbook of Barddhman District, Sonepur Bazari OCP website and records of local anganwadi centres. Though the data available through secondary sources are valuable, they are inadequate for developing critical insights into the objectives and hypotheses as mentioned above. Hence, special effort was undertaken to obtain relevant data from primary source. A sample survey was essential to get the real picture of that region.

One of the objectives of the study was to survey the levels of dispossession in the mining affected villages based on their differential social composition. The survey villages are chosen from the list of affected villages (Table 2) published by Sonepur Bazari Opencast Project on their official website. At the very first stage the affected villages are divided into three categories based on their social composition. They are:

(1) Tribal dominated villages (Arsula, Bheladanga, Kuchibera, Basabdanga, Bandhghat, Madhudanga)

(2) Scheduled caste(SC) dominated villages (Ruidaspara, Bhaluka, Bhatmura)

(3) Non-tribal mixed character villages (Hansdiha,Bazari,Sonepur,Shankarpur)

It is noteworthy to mention that the sample villages for the study have been chosen from those which are already affected by the open cast project. All the villages mentioned here are not census villages. After going through the data from various secondary sources (like District Census Hand book, Sonepur Bazari OCP website and records of local anganwadi cetres) it was decided to conduct the survey in one or two villagesfrom every category.

(1) Tribal dominated:The selected two villages from this category are Arsula (45 households) and Kuchibera (30 households). Both the villages are typical tribal villages.

(2) Scheduled caste dominated: Bhaluka village (32 households) was selected from this category. This village is a scheduled caste dominated village. However, heterogeneity in economic status is quite visible within the SC population of this village. 
(3) Non-tribal mixed character: Hansdiha (45 households) and Sonepur (50 households) villages were selected from this category for the purpose of the survey. The objective is to select such villages where people from different non-tribal social groups are residing in one place.

In each of the five villages, a sample survey of households was conducted in 2015 in order to collect detailed data on basic socio-economic conditions, land acquisition, compensation provided, awareness of the people about land acquisition and compensation received, etc. In each village, the number of samples was chosen to ensure that it could be statistically satisfied. Interviews from the randomly selected households (202 households) were conducted with the help of structured questionnaires. The data were processed with the help of SPSS software.

\section{- $\quad$ Statistical Methodology}

For an accurate analysis of primary data very simple statistical methods (like cross tabulation and percentage calculation) are used.

\section{- Cartographic Methodologies}

Apart from these statistical methods cartographic methods like bar graph are used for the graphical representation of analysed dataset. On the other hand, for mapping purpose Arc GIS 9.3 software is used.

\section{- $\quad$ Content Analysis}

To support the empirical evidences and find out social, economic and geographic significance of the study, content analysis is very essential.

\section{Tribal Dispossession: Theoretical Formulations}

There are quite a few strong theoretical explanations for tribal dispossession. This paper uses Marx'stheory of'Primitive Accumulation'and Harvey'stheory of 'Accumulation by Dispossession' to show how different policies enable mining corporations to locate and develop resources in areas dominated by tribal population and destroy their natural habitat and traditional subsistence means of livelihoods. Accumulation by dispossession is the integral part of the deepening commoditisation of physical, cultural and social environment (Whitehead, 2010). These include not only land but also water, forest and forest products, seeds, organic fertilisers and pesticides, herbal medicines, folksongsand resources which were part of common heritage and possession and knowledge of indigenous societies throughout the world (lbid). Harvey used this concept for the study of how indigenous modes of production are replaced by capitalist mode of production. The tribals and the poor located in the margins of society are systematically deprived of their means of livelihoods and forced to seek work from the affluent, powerful and dominantsections of the society.

\section{Mining: A Specific Example of Accumulation by Dispossession}

As Perreault (2012) notes, 'mining radically transforms landscapes.' The term landscape used here refers to not only physical landscape butalso social, economic and political landscape. The initial stage of mining operation in India exemplifies Marx's concept of 'Primitive Accumulation'. During the earlier days of mining, the local Zamindars were the owners of the mines. They were interested in opening up new collieries.As put forth by Lahiri-Dutt (2003), 'the ownership of land in Raniganj region had passed 
from local adivasis (indigenous people) to agricultural casteslong before coal mining caught on as a popular business enterprise with the Zamindars.' They were the largest land owners, the leading employers of the regional labour market and also the resource movers in the single industry region. Astheagriculture sector receded due to the expansion of the mining sector, the local inhabitants wereforced to seek jobsin other sectors and what could bethe alternative options for them in a single industry region? Therefore, they became part of the labourforce involved in mining activities. This is what Marx described as the process of transformation from the social means of subsistence and production into capital and accumulation of that capital in the hands of few, in addition to, transformation of immediate producers into wage labourers.'

The Indian mining sector has been experiencing profound changes ever since the Government of India announced its New Mineral Policy in 1994. The new policy started to release the asset (land) in the market not only to the privateinvestors but also to global mining giants for activities like excavation, haulage, drilling, blasting and other ancillary ones. Private investment in mining is an apt example of what Harvey illustrates as the neo-liberal tendency to release assets at a low cost by the State, where private investors immediately seize hold of those assets and divert them towards profitable use. Present study of Sonepur Bazari open cast project is an illustrative example from eastern coal mining region of India.

The Sonepur Bazari project is the largest producer of coal in West Bengal. This project has received financial support from World Bank group. Being an open cast project, it requires a vast area of land to extract coal. Presently, the excavation and haulage activities of Sonepur Bazari project are operated by the private companies like ICl and Mahalaxmi Company. The responsibility kept with ECL is to acquire land from the commons and hand it over to these companies. According to the official estimates, the open cast mines of Sonepur Bazari open cast mega project is spread over approximately 2404.85 hectares of land. It has already physically dispossessed several tribal and non-tribal villagesand will do even more by 2025. There is an official estimate of number of people and households affected by the Sonepur Bazari Project on their official website. However, the project authorities have only estimated the number of displaced population but do not document the reality of dispossession.

The above-mentioned case shows that the new mineral policymakes the sectormore liberal and more lucrative for private investment in mining. Pedal and Das (2010) have arrived at a conclusion that:

The aim of the new mineral policy is to encourage in mining and speed up clearance procedure for exploration as well as actual mining. The role outlined for the government is as 'facilitator' for mining companies, keeping at'arm's length from direct involvement, in line with neo-liberal orthodoxy.'

Most of the mineral resources are concentrated in the tribal dominated regions (Kothari, 1996). To find an economically viable concentration of coal mining companies require asmuch accumulation of land as possible. Hence, the utmost burden of displacement and dispossession is borne by those sections of the society who largely live in those areas and depend on natural resources like land, forest, etc. Physical displacement perhaps is the most prominent form of dispossession, but it is only part of the 
overall scenario which extended to other spheres as well. Other forms of dispossession by mining activities include economic dispossession, environmental degradation and cultural dispossession including forced assimilation, extermination of subaltern rights and their ways of living. What is noteworthy is that the process of dispossession is a process of negotiation between the capitalists and the State where the common people, in general, and the tribals, in particular, have been the victims by the act of expropriation of resources (Lahiri-Dutt, Krishnan and Ahmed, 2012).

\section{Dispossession Scenario: Findings from Field}

Mining and Mineral Resources of Raniganj Coal

Belt: Sonepur Bazari is located in the Raniganj Coalfields region of West Bengal. This region is well endowed with coal resources and also the abode of thousands of population with or without legal entitlements. This region has a long history of mining but the coal production from the underground minesforpublic utilisation has been viewed as underutilised. After 1990s, CIL introduced modernisation programme to increase the economic use of coal resource. It decided to change the production process into open cast mining to increase the profit by reducing production cost and increasing productivity. But the OCPs required a vast array of land for large scale production. The authority has taken possession of the terrain resided by both tribals and non-tribals followed by Coal Bearing Area Act, 1957. Accumulation of capital on land through mining activity boomed as land is acquired almost either free of cost or on very minimum cost.

Table 1: Revenue Villages from Where Land Has Been Acquired for Open Cast Mining

\begin{tabular}{|c|c|c|c|c|c|}
\hline $\begin{array}{l}\text { Area Acquired } \\
\text { in Hectare (April, 2014) }\end{array}$ & Block & $\begin{array}{c}\text { Mouza from } \\
\text { Where Land } \\
\text { Acquired }\end{array}$ & $\begin{array}{l}\text { Mouza } \\
\text { JL No. }\end{array}$ & $\begin{array}{l}\text { Villages from } \\
\text { Which People } \\
\text { Already } \\
\text { Displaced/ } \\
\text { Transitional } \\
\text { Phase } \\
\end{array}$ & $\begin{array}{c}\text { Villages } \\
\text { from Which } \\
\text { People Lost } \\
\text { Land }\end{array}$ \\
\hline CBA Act Ph-I (68.01 ha) & & Bazari & 23 & Bazari & \\
\hline CBA Act, Ph-2 (547 ha) & & Bhaluka & 21 & Bhaluka & \\
\hline $\begin{array}{l}\text { CBA Act Ph-III, (1200 ha) } \\
\text { LA Act (398.54) }\end{array}$ & Pandaveshwar & Bhatmura & 13 & Bhatmura & \\
\hline Inherited (38.58) & & Hansdiha & 27 & Hansdiha & \\
\hline Govt. Iand (42.65) & & Haripur & 24 & & Haripur \\
\hline $\begin{array}{l}\text { Direct Purchase Ph-I } \\
\text { (110.07 ha) }\end{array}$ & & Konardihi & 14 & Konardihi & \\
\hline Total (2404.85 Ha.) & & $\begin{array}{l}\text { Kumarkhala } \\
\text { Nabagram } \\
\text { Sonepur }\end{array}$ & $\begin{array}{l}25 \\
20 \\
22\end{array}$ & $\begin{array}{l}\text { Kumarkhala } \\
\text { Nabagram } \\
\text { Sonepur }\end{array}$ & \\
\hline
\end{tabular}

Journal of Rural Development, Vol. 36, No. 2, April - June : 2017 
Table 1 (Contd.....)

\begin{tabular}{|c|c|c|c|c|c|}
\hline $\begin{array}{l}\text { Area Acquired } \\
\text { in Hectare (April, 2014) }\end{array}$ & Block & $\begin{array}{c}\text { Mouza from } \\
\text { Where Land } \\
\text { Acquired }\end{array}$ & $\begin{array}{l}\text { Mouza } \\
\text { JL No. }\end{array}$ & $\begin{array}{c}\text { Villages from } \\
\text { Which People } \\
\text { Already } \\
\text { Displaced/ } \\
\text { Transitional } \\
\text { Phase } \\
\end{array}$ & $\begin{array}{c}\text { Villages } \\
\text { from Which } \\
\text { People Lost } \\
\text { Land }\end{array}$ \\
\hline & Ondal & Shankarpur & 28 & Shankarpur & \\
\hline & Jamuria & Chinchuria & 69 & & Chinchuria \\
\hline & & Dahuka & 70 & & Dahuka \\
\hline
\end{tabular}

Source: http://easterncoal.gov.in/area/sonepurbazari.html and http://banglarbhumi.gov.in/.

The Sonepur Bazari OCP was conceived in the last two decades of 20th century.According to the official estimates, the open cast mines of Sonepur Bazari open cast mega project are spread over approximately 2404.85 hectares of land (Table 1,Figure 1).It has already dispossessed several tribal and non-tribal villages under Pandaveshwar, Jamuria and Ondal blocks physically and will do even more by 2025 . The majority of the displaced population is rehabilitated within $5 \mathrm{~km}$ of their prior location, at Dahuka Mouza. There is an official estimate of number of people and households (Table 2) affected by the Sonepur Bazari project. The project authorities have only estimated displaced population but did not document the reality of dispossession.

Table 2: Social Composition and Main Livelihoods of the Households of the Displaced Villages in Sonepur Bazari Open Cast Mining Region

\begin{tabular}{|c|c|c|c|c|c|c|c|}
\hline$\overline{S .1}$ & Village & $\begin{array}{l}\text { Total } \\
\text { Popu- } \\
\text { lation }\end{array}$ & $\begin{array}{c}\text { Total } \\
\text { House- } \\
\text { holds } \\
\text { (already } \\
\text { displaced/ } \\
\text { to be } \\
\text { displaced) }\end{array}$ & $\begin{array}{c}\text { Average Size } \\
\text { of the } \\
\text { House- } \\
\text { hold }\end{array}$ & $\begin{array}{l}\text { Social } \\
\text { Compo- } \\
\text { sition }\end{array}$ & $\begin{array}{l}\text { Main } \\
\text { Liveli- } \\
\text { hood }\end{array}$ & $\begin{array}{l}\text { Year of } \\
\text { Displace- } \\
\text { ment }\end{array}$ \\
\hline 1 & Punjabi Danga & 317 & 119 & 2.66 & Migrants & Self Employed & 2000 \\
\hline 2 & Hansdiha & 482 & 210 & 2.30 & Mixed & $\begin{array}{c}\text { Miner, } \\
\text { Daily Wage } \\
\text { Labour }\end{array}$ & 2004 \\
\hline 3 & Bheladanga & 212 & 94 & 2.56 & Mixed & $\begin{array}{c}\text { Daily Wage } \\
\text { Labour }\end{array}$ & 2006 \\
\hline
\end{tabular}


Table 2 (Contd.....)

\begin{tabular}{|c|c|c|c|c|c|c|c|}
\hline S. No & Village & $\begin{array}{l}\text { Total } \\
\text { Popu- } \\
\text { lation }\end{array}$ & $\begin{array}{c}\text { Total } \\
\text { House- } \\
\text { holds } \\
\text { (already } \\
\text { displaced/ } \\
\text { to be } \\
\text { displaced) }\end{array}$ & $\begin{array}{c}\text { Average Size } \\
\text { of the } \\
\text { House- } \\
\text { hold }\end{array}$ & $\begin{array}{l}\text { Social } \\
\text { Compo- } \\
\text { sition }\end{array}$ & $\begin{array}{l}\text { Main } \\
\text { Liveli- } \\
\text { hood }\end{array}$ & $\begin{array}{c}\text { Year of } \\
\text { Displace- } \\
\text { ment }\end{array}$ \\
\hline 4 & $\begin{array}{l}\text { Ruidaspara } \\
\text { (Sonepur) }\end{array}$ & $200+2158$ & $64+550$ & 3.84 & Mixed & $\begin{array}{c}\text { Miner, } \\
\text { Daily Wage } \\
\text { Labour }\end{array}$ & $\begin{array}{l}1996 \text { to } \\
2016-17\end{array}$ \\
\hline 5 & Arsula & 300 & 100 & 3 & $\begin{array}{c}\text { Tribal } \\
\text { Dominated }\end{array}$ & $\begin{array}{l}\text { Daily Wage } \\
\text { Labour }\end{array}$ & $\begin{array}{c}2013-14 \& \\
2014-15\end{array}$ \\
\hline 6 & Bhaluk & 347 & 55 & 6.31 & SC Dominated & Miners & 2014-15 \\
\hline 7 & Kuchibera & 250 & 50 & 5 & $\begin{array}{c}\text { Tribal } \\
\text { Dominated }\end{array}$ & $\begin{array}{c}\text { Daily Wage } \\
\text { Labour }\end{array}$ & 2014-15 \\
\hline 8 & Basabdanga & 300 & 100 & 3 & & & 2014-15 \\
\hline 9 & Bandhghat & 80 & 30 & 2.67 & & & 2014-15 \\
\hline 10 & Madhudanga & 400 & 130 & 3.0 & & & 2019-20 \\
\hline 11 & Bhatmura & 500 & 130 & 3.8 & & & 2019-20 \\
\hline 12 & Bazari & 2409 & 385 & 6.26 & Mixed & Miner & 2019-20 \\
\hline 13 & Nabag & 4 & 500 & 9.2 & Mixed & Miner & 2019-20 \\
\hline 14 & Sankarpur & 900 & 160 & 5.63 & Mixed & Miner & 2019-21 \\
\hline
\end{tabular}

Source: http://easterncoal.gov.in/area/sonepurbazari.html and Field Survey (Summer, 2015).

Figure 1: Revenue Villages in Pandaveshwar, Ondal and Jamuria Blocks from Where Land Has Been Acquired for Open Cast Mining (Till April, 2014)

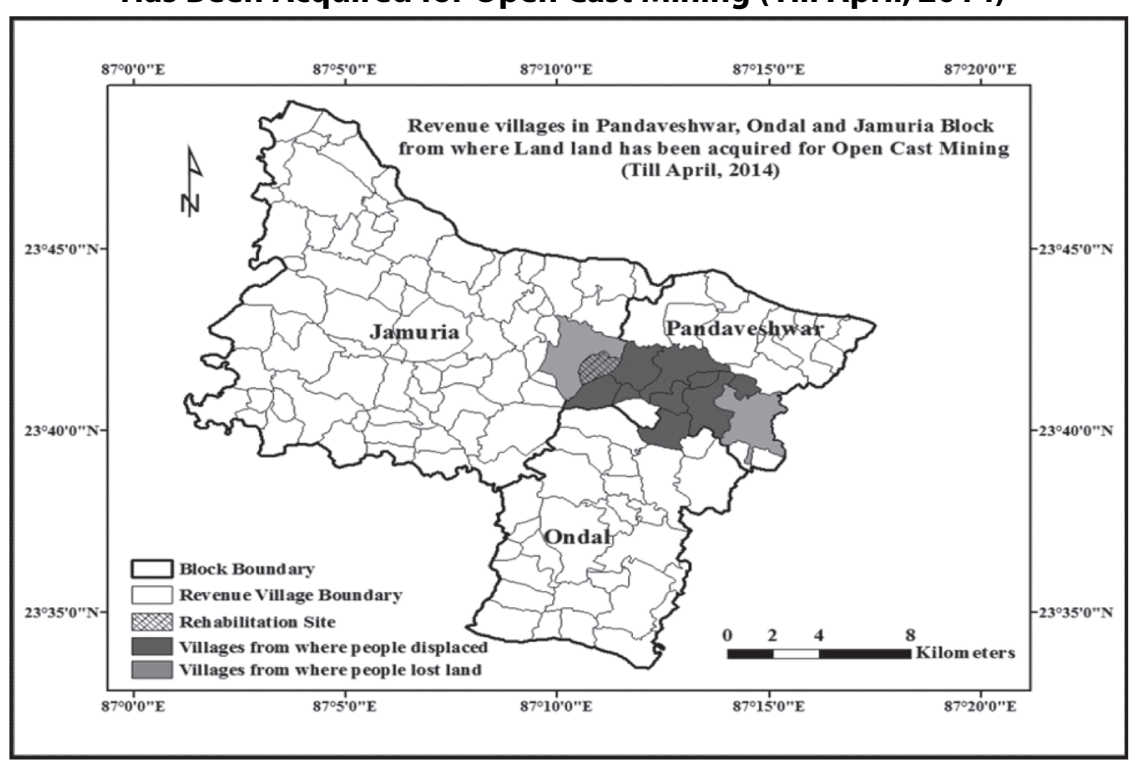

Source: Census of India, 2011 (Village Boundary Map). 
Table 2 also providesan overview of some socio-economic parameters of the villages from which physical dispossession has taken place or to be taken place due to expansion of OCPs. Land acquisition for the purpose of mining led to two forms of economic differentiation in this region: inter-village and intra-village. Inter-village differentiations essentially stemmed from degree of landholdings. In some villages such as Arsula, Kuchibera, Basakdanga, Bandhghat, Banglapara, virtually all the households belong to tribal communities like Hansda, Kora, Murmu, Besra, etc. In such villages, presently people are mainly involved in casual daily employment in thenon-agriculture based sector. In othervillages such as Hansdiha, Bhaluka intra-village economic inequalities between households involved in regular salaried mining jobs and those dependent on daily wage labour are noticeable. Several intersecting variables make the situation even more complex. The categorisation is made not only to suggest the social structure but also has relevance for analysing the magnitude of dispossession among these categories.

The economy of the adivasis of mining region of West Bengal is characterised by both subsistence production and direct dependence on natural resource base. Earlier they were dependent on agriculture, livestock and gathering of various forms of forest products for their livelihood. Coal resource always had an important place in their life. The degree of selfsufficiency by cultivation, using livestock and collecting forest products and coal were restricting them from interacting with the market economy.

Adivasisgenerallyutilise land in two ways: to make up a village hamlet and for the purpose of cultivation. But cultivation of land for them is quite a problematic practice, as they encroached upon the land belonging either to the private land owners or to the ECL authority.Despite the overall subsistence characteristics, adivasis also havea degree of interaction with the local market economy. They collect coal resource from the surrounding coal mines and sell those to the local merchants to get cash. But it is also true that in the market-based economy the tribals find themselvesin a disadvantageous position as they have a very little and blurred idea about the market economy. Additionally, since the beginning of the 21st century, land acquisition by ECL has not only dispossessed physically of their rights but pushed them towards more market-oriented structure.

\section{Contextualising Dispossession over Social}

Space: The field experiences support the argument that the social identity of the tribals implies their backwardness partly, because locational specificities do impact their behaviour. Only a small segment of the population is able to bargain for its rights while historically and socioeconomically the marginalised sections continue to remain outside the circle. The expansion of OCP over Sonepur Bazari led to substantial changes in the economic and social fabric of the communities. Many of these changes have adversely affected the communities in general and the tribals in particular.This study proposes to provide an understanding of the dimensions of dispossession using Michael Cernea's Impoverishment Risks and Reconstruction (IRR) Model (Cernea, 1997).

Landlessness: According to Agarwal (1996), among economic resources, land has its dual importance as productive asset and as potential income stream. It provides the source of economic security in a number of ways: through 
direct production possibilities as saleable asset, provide employment to others and so on. Land owning class tends to have greater bargaining power than the landless ones. The tribals and the dalits, because of their financial insecurity can easily be convinced to trade in that asset for a cash payment at relatively low price. Because of low level of literacy and awareness, the tribals are unable to understand the politics of land acquisition practice. Cash compensation and land for land (only homestead) is not adequate to make up the utility of the land. That is why landbased risk need to be differentiated across social space.
In case of Sonepur Bazari project landlessness for the small landholders, artisans, shopkeepers and especially for the tribalsmeans greater insecurity than for the large landholders. The R\&R policy of CIL officially makes the landowners the beneficiaries by offering them regular salaried jobs in the formal sectors (mining) and turns the self-sufficient economy of the tribals into market-based economy. Even though each project affected person (mainly male) irrespective of his social identity gets homestead land ascompensation, the quality of land provided to the tribals was problematic and need to be assessed tactfully by the practitioners.

Table 3: Land Rights and Agricultural Use Across Different Social Groups

\begin{tabular}{lcccccc}
\hline Social Group & $\begin{array}{c}\text { Land } \\
\text { Owners }\end{array}$ & Sharecroppers Encroachers & $\begin{array}{c}\text { Landless } \\
\text { Agricultural } \\
\text { Labourers }\end{array}$ & $\begin{array}{c}\text { Never } \\
\text { Involved } \\
\text { in Agriculture }\end{array}$ & Total \\
\hline Scheduled & 0 & 6 & 32 & 39 & 5 & 82 \\
Tribe & $(0.00)$ & $(7.32)$ & $(39.02)$ & $(47.56)$ & $(6.10)$ & $(100.00)$ \\
Scheduled & 35 & 3 & 0 & 16 & 0 & 54 \\
Caste & $(64.81)$ & $(5.56)$ & $(0.00)$ & $(29.63)$ & $(0.00)$ & $(100.00)$ \\
Others & 66 & 0 & 0 & 0 & 0 & 66 \\
& $(100.00)$ & $(0.00)$ & $(0.00)$ & $(0.00)$ & $(0.00)$ & $(100.00)$ \\
Total & 101 & 9 & 32 & 55 & 5 & 202 \\
& $(50.00)$ & $(4.46)$ & $(15.84)$ & $(27.23)$ & $(2.48)$ & $(100.00)$ \\
\hline
\end{tabular}

Source: Author's analysis, based on field survey carried out in 2015.

Landlessness brings greater risks for the landless population irrespective of social identity, in comparison to the landowning class. The tribals in Arsula, Bandhghat, Bandhghat, Chatimdanga and Banglapara have for long cultivated the land near their villages with no records of rights. However, the legal rights were kept with the nontribal villages. Thus, now, when the tribals are being displaced, they are not getting any compensation for the land, as they have been cultivating land only as encroachers and not as land owners. Survey figure (Table 3) shows that almost 39 per cent tribals are encroachers. Comparing social groups regarding land rights, it is found that highest proportion of households with legal land rights are found among others, followed by the SCs. Thus, the non-tribals get better opportunities as far as CIL R\&R policy is concerned. 
Physical Dispossession: The accumulation of private and communal land for the expansion of mining results in massive displacement of people in the Sonepur Bazari area. Homelessness due to physical displacement by mining is a temporary phenomenon as the ECL authority is providing both homestead land and cash compensation for house building to all the project affected families irrespective of class and caste identity.But, there are lots of loopholes in the R\&R policy of CIL.

In case of SonepurBazari project, the major discrimination is centred on the monetary assessment of the houses. Families having pucca houses are getting monetary compensation on per square metre basis. Whereas the CIL R\&R scheme appraises the kaccha houses of the rural poor and tribals as having very less economic value and a fixed as well as limited amount.

Table 4: House Structure Across Social Groups

\begin{tabular}{lcc}
\hline Social Groups & \multicolumn{2}{c}{ House Structure } \\
& Pucca House & Kaccha House \\
\hline Scheduled Tribe & $4(4.88)$ & $78(95.12)$ \\
Scheduled Caste & $35(64.81)$ & $19(35.19)$ \\
General Caste & $64(96.97)$ & $2(3.03)$ \\
Total & $103(50.99)$ & $99(49.01)$ \\
\hline
\end{tabular}

Source: Author's analysis, based on field survey carried out in 2015.

It is hardly necessary to show the figures (Table 4) in order to understand the compensation amount the tribals are getting, which is quite less to build up a pucca structure. Similarly, it is also true that the authorities are also trying to reduce the inequality between the tribalsand non-tribals by providing the same size of plot (100 sq. mts.) to every project affected person (PAP). A major discrimination is noticed during the time of survey. The tribal villagers of Arsula recorded a sudden move to their new rehabilitation site without any prior notice. They were provided with few temporary structures. Contrary to this, all the PAFs from other villages(Hansdiha, Bhaluka, etc.) have only shifted to the site once they are completely done with their new house and other necessary infrastructure.

Occupational Shift: Occupation dispossession was started even before physical dispossession. The process of land acquisition has been taking place since 1996. The continuous processes of land acquisition have reduced the availability and quality of agricultural land. It has turned the region an economically depressed area for the survival of the adivasis. Later,the tribals of Sonepur Bazari region have been thrown out of their land and indirectly forced to shift to a new place. It is evident that the entire community is still staying together on a new physical space but disrupted by the class structure. Land acquisition for the purpose of mining leads to occupational dispossession among the landless. They are not absorbed in the formal mining sectors. Thestatus of daily wage labourer remainsthe same, whereas a shift is found from agriculture-based sector to non-agriculture based sector. For the tribals of Sonepur Bazari region, who have been dispossessed from their land, it is difficult for them to create an alternative source of livelihood. This problem arises specially during the transitional phase and continues even after few years. 
Table 5: Nature of Employment Across Social Space

\begin{tabular}{lcccccc}
\hline Social Group & $\begin{array}{c}\text { Self- } \\
\text { employed }\end{array}$ & $\begin{array}{c}\text { Regular } \\
\text { Wage/ } \\
\text { Salary } \\
\text { earning/ } \\
\text { Perma- } \\
\text { nent }\end{array}$ & $\begin{array}{c}\text { Regular } \\
\text { Casual } \\
\text { Labour }\end{array}$ & $\begin{array}{c}\text { Daily } \\
\text { Casual } \\
\text { Labour }\end{array}$ & $\begin{array}{c}\text { Regular } \\
\text { Contract } \\
\text { Employ- } \\
\text { ment }\end{array}$ & $\begin{array}{c}\text { Daily } \\
\text { Contract } \\
\text { and } \\
\text { Unregis- } \\
\text { tered } \\
\text { Employ- } \\
\text { ment }\end{array}$ \\
\hline Scheduled Tribe & 10 & 4 & 3 & 56 & 5 & 4 \\
Scheduled Caste & $(12.20)$ & $(4.88)$ & $(3.66)$ & $(68.29)$ & $(6.10)$ & $(4.88)$ \\
General Caste & 7 & 29 & 0 & 14 & 4 & 0 \\
Total & $(12.96)$ & $(53.70)$ & $(0.00)$ & $(25.93)$ & $(7.41)$ & $(0.00)$ \\
& 5 & 56 & 0 & 0 & 5 & 0 \\
& $(7.58)$ & $(84.85)$ & $(0.00)$ & $(0.00)$ & $(7.58)$ & $(0.00)$ \\
& 22 & 89 & 3 & 70 & 14 & 4 \\
& $(10.89)$ & $(44.06)$ & $(1.49)$ & $(34.65)$ & $(6.93)$ & $(1.98)$ \\
\hline
\end{tabular}

Source: Author's analysis, based on field survey carried out in 2015.

It is also found that thenon-tribal landless population (Hansdiha village) which has been dispossessed around 10 years ago could manage alternate source of livelihoods. They are either working as daily wage labourers in the construction site or in the local brick kilns. On the other hand, the secure employment opportunities in the mining sector are monopolised by the largescale land owning class. In addition, it is important to mention (documented in the R\&R policy of $\mathrm{CIL}$ ) that affected tribal families will get one time financial assistance of 500 days of MAW for loss of customary rights. But the condition is, they have to produce tribal identity certificate issued by a Sub-Divisional Officer. From the field survey it is recorded that around 80 per cent of the tribal households do not have any identity proof.This may be viewed as CIL policy seems to have no in-built mechanism to resolve the problem of discrimination.
Food Insecurity : The risk of food insecurity is considered as part of dispossession. The field survey shows that there is hardly any relation between food security and income of the households for the poor in general and for the tribals in particular. Decrease in the natural resource base increases food insecurity among those sections of the society who are dependent on forest products and other natural resources (like fish from water bodies) for food. Although it was difficult to assess the issue of food security accurately, persons interviewed werequestioned about how they arrange their food for everyday consumption and whether they are facing any problem regarding daily intake. Most of the households interviewed in the tribal villages, in general, are highly dependent on the natural and communal resourcesfor daily consumption. On the basis of the information gathered from field survey, it is quiteevident that tribal families hardly 
have adequate diets in terms of daily consumption. More than 90 percent of the tribal and poor households kept cows and chickens and had an adequate supply of milk and eggs. But in the resettlement site as the families are not getting adequate space, it is not possible for them to keep these cows and chickens. According to the testimonies of villagers, about 80 percent tribal households have sold out their cows before shifting to the new site due to scarcity of space. Now it is not possible for them to buy everything from the market. Though it is also evident that in the tribal areas of Sonepur Bazari project where the displaced population is given cash compensation, the tendency to spend cash compensation for goods from the market (including food) and become destitute is a familiar picture.

Social Disarticulation and Cultural Genocide:As Dhagamwar (2011) notes, 'outside their traditional and historical habitat, they are like fish out of water.'For tribals ancestral land is their life support system. Theirvery identity (socio-cultural) is tied to theland. Mining is a threat to their ethno- diversity. According to the R\&R policy of CIL, male members having age of 18 and above within the project affected families are eligible to get resettlement benefits. They get separate homestead land and money as well. Therefore, fragmentation in the family is a common feature of the resettled villages. This kind of fragmentation may be viewed as one form of social disarticulation.

\section{Loss of Access to Common Property Resources:} Overall, tribal location seems to have a profound effect on access to common property resources (CPRs). It can be observed that loss of CPRs has devastating impact on both the rural poor and the tribals. Due to dependency on natural resource base tribals felt the impact more severe. The Sonepur Bazari story shows that the tribals have lost hold of forest, water bodies and grazing landsbecause of mining. They have sold out their livestock due to scarcity of grazing land. Moreover, they are also facing the problem of access to water. The R\&R policy hardly could restore access to common property resources after physical dispossession.

Table 6: Changes Among the Communities After Physical Dispossession Due to Mining: A Summary

\begin{tabular}{|c|c|c|c|c|}
\hline \multirow[t]{2}{*}{ Aspect } & \multicolumn{2}{|c|}{ Tribal Practices } & \multicolumn{2}{|c|}{ Non-tribal Practices } \\
\hline & Customary & Contemporary & Customary & Contemporary \\
\hline Land right & $\begin{array}{l}\text { Community rights. } \\
\text { Only few had } \\
\text { privatelands. }\end{array}$ & $\begin{array}{l}\text { Right on deed of } \\
\text { license with } \\
\text { selling right. }\end{array}$ & $\begin{array}{l}\text { Private land } \\
\text { ownership. But } \\
\text { size of landholding } \\
\text { varies. }\end{array}$ & $\begin{array}{l}\text { Right on deed of } \\
\text { license with } \\
\text { selling right. }\end{array}$ \\
\hline Habitat structure & $\begin{array}{l}\text { Mainly kaccha } \\
\text { structure. }\end{array}$ & Puccastructure. & $\begin{array}{l}\text { Varies from pucca } \\
\text { to kaccha on the } \\
\text { basis of economic } \\
\text { status. }\end{array}$ & Puccastructure. \\
\hline
\end{tabular}


Table 6 (Contd......)

\begin{tabular}{|c|c|c|c|c|}
\hline \multirow[t]{2}{*}{ Aspect } & \multicolumn{2}{|c|}{ Tribal Practices } & \multicolumn{2}{|c|}{ Non-tribal Practices } \\
\hline & Customary & Contemporary & Customary & Contemporary \\
\hline Occupation & $\begin{array}{l}\text { Agricultural labour, } \\
\text { collecting forest } \\
\text { products, food } \\
\text { gathering. }\end{array}$ & $\begin{array}{l}\text { Non-agriculture } \\
\text { based informal } \\
\text { sectors. }\end{array}$ & $\begin{array}{l}\text { Cultivators to } \\
\text { agricultural labour } \\
\text { depend on } \\
\text { landholdings. }\end{array}$ & $\begin{array}{l}\text { People with large- } \\
\text { scalelandholdings } \\
\text { become regular } \\
\text { salaried workers in } \\
\text { formal mining } \\
\text { sector.Small scale } \\
\text { landholders and } \\
\text { landless } \\
\text { population } \\
\text { become daily } \\
\text { wage labour in } \\
\text { non-agriculture } \\
\text { based informal } \\
\text { sector. }\end{array}$ \\
\hline Economy & $\begin{array}{l}\text { Self-sufficient, } \\
\text { subsistence } \\
\text { economy. }\end{array}$ & $\begin{array}{l}\text { Market-based } \\
\text { economy. } \\
\text { Disadvantageous } \\
\text { situation. }\end{array}$ & $\begin{array}{l}\text { Both market-based } \\
\text { and subsistence } \\
\text { economy. }\end{array}$ & $\begin{array}{l}\text { Entirely market- } \\
\text { based economy. }\end{array}$ \\
\hline Food security & $\begin{array}{l}\text { Food security is } \\
\text { not dependent on } \\
\text { income but } \\
\text { availability of } \\
\text { natural and } \\
\text { communal } \\
\text { resources. Hence, } \\
\text { secured. }\end{array}$ & $\begin{array}{l}\text { Food insecurity } \\
\text { increases due to } \\
\text { decline in access } \\
\text { to natural and } \\
\text { common property } \\
\text { resources. }\end{array}$ & $\begin{array}{l}\text { Food security is } \\
\text { dependent on } \\
\text { cultivation. }\end{array}$ & $\begin{array}{l}\text { Food security } \\
\text { becomes } \\
\text { dependent on } \\
\text { earning and } \\
\text { market. }\end{array}$ \\
\hline Social structure & $\begin{array}{l}\text { i. Mainly } \\
\text { egalitarian } \\
\text { society. } \\
\text { ii. Joint family } \\
\text { structure. }\end{array}$ & $\begin{array}{l}\text { i. Classhierarchy } \\
\text { among the } \\
\text { tribals. } \\
\text { ii. Fragmentation } \\
\text { of family. }\end{array}$ & $\begin{array}{l}\text { i. Class } \\
\text { differentiated } \\
\text { society. } \\
\text { ii. Joint family } \\
\text { structure. }\end{array}$ & $\begin{array}{l}\text { i. Class } \\
\text { differences still } \\
\text { exist. } \\
\text { ii. Fragmentation } \\
\text { of family. }\end{array}$ \\
\hline Access to CPRs & $\begin{array}{l}\text { Considerable, as } \\
\text { highly dependent } \\
\text { on natural } \\
\text { resources. }\end{array}$ & $\begin{array}{l}\text { Restriction on } \\
\text { tribal access to } \\
\text { CPRs. }\end{array}$ & $\begin{array}{l}\text { Wasnot } \\
\text { dependent on } \\
\text { natural resources } \\
\text { completely. }\end{array}$ & $\begin{array}{l}\text { Access to natural } \\
\text { resources even } \\
\text { more restricted. }\end{array}$ \\
\hline
\end{tabular}


The above scenario (Table 6) shows how somegroupsaremorevulnerablethan theothers and also admits that land acquisition fetches different sets of problems of dispossession for different stakeholders.

\section{Relative Dispossession among Tribals: A Discussion}

TheSonepur Bazari casestudy shows that there is no doubt that in few aspects tribals are more deprived than the non-tribals when the issue of State and capital intrusion in the rural hinterland is marked by the process of displacement and dispossession.A micro level study in the field would reveal the factors which embody these inequalities.

Multiple Laws with Overlapping Content: These kinds of inequalities are existing not just because tribal people have always been at the peripheries of development but also by some specific policies of land acquisition by the State. Guha (2001) mentions that the policies are very dynamic in nature and change very quickly within a short time interval. Today the land acquisition in the coal mining areas is governed mostly by the CBA Act, 1957 (applicable to all the States other than Jammu and Kashmir). As per the provisions of CBA Act, land is taken away by the government from the tribal and non-tribal population and can be handed over to the private companies for excavation, haulage, drilling, blasting and ancillary activities.The current CBA Act does not need consent of the land owners and users before acquiring the land. Private property rights in this case are unable to provide any protection. The issues of tribal rights have received very little attention in the policy formulation. Tribals'right to property is merely a legal right under article 300 of Indian Constitution and not a fundamental right, where State can acquire their property with just compensation by the authority of law. There are few laws to protect tribal land rights. Legislations like West Bengal Land Reform Act, SC and ST Protection Act, Forest Conservation Act are the Acts which protect tribal rights on their landsand livelihoods but unable to do so finally because of poor implementation (Pedal and Das, 2010).Tribals will lose the constitutional rights after displacement. Regardless of legislative protection provided by the Indian Constitution, large-scale land acquisition and tribal dispossession is quite evident. Undereminent domain, the government is the owner of all the natural resources found in air, water and land. In that sense, the land underneath where valuable mineral resources are found, by virtue of the Indian law, belong to the government. The rules framed under the Mining and Minerals (Regulation and Development) Act, 1957 are important ones on mining. This law, however, contradicts theWest Bengal Land Reform Act which protects the land rights of the tribals by restricting the transfer of land rights to the non-tribals. Basically, CBA Act has its supremacy as far as implementation process is concerned. In the Schedule V Areas, they enjoy a unique set of constitutional rights and privileges, which would no longer be available, once they are uprooted from these areas.Thus,the existing lawsare the major sources of inequalities.

R\&R Policy of CIL with Fault Lines: The formulation of contemporary policies on Resettlement and Rehabilitation (R\&R) is the outcome of a complex process of interaction between the State and corporate interests and different stakeholders of the society. There is interplay of varying ideologies and interests. In recent years, $\mathrm{ClL}$ has become more conscious about the unrest and protest over land acquisition, one of the main issues of Indian 
politics and therefore, has brought several changes in R \& R policies. Pedal and Das (2011) observed, for instance, that most of the $R \& R$ policies do not assess the economic value of the traditional tribal houses.CIL hasitsown R\&Rpolicy, where special attention has been provided to the tribals. At the same time, it is not very easy to practise it on the ground. According to the testimonies of the villagers, sometimes the government officials give less information or misinformation in the meetings and overpublicise about the facilities provided to the project affected population through resettlement and rehabilitation scheme. Most of the time villagers'opinions are not taken into consideration and even they get threats that if they don't accept the compensation, will be the ultimate losers. The government officials promised the villagers to provide good R\&R package, as a part of which they will get all the facilities that were available in the previous villages and can get even more and also try to convince the villagers that they will not have problems of blasting as is the case now since they are residing close to the quarry area. It can be stated that apart from multiple laws, dispossessed populations are often caught by the faulty $R \& R$ policies and its intricate implementation procedure.

Lack of Information: The empirical evidences gathered from the field survey indicate that the tribals are hardly aware of their rights that contemporary laws have promised them. As mentioned by Kothari (1996), planners, administrators and the elites invariably manipulate the tribals as they are unaware of the real situation.

Figure 2: General Awareness Regarding Displacement Across Different Social Groups

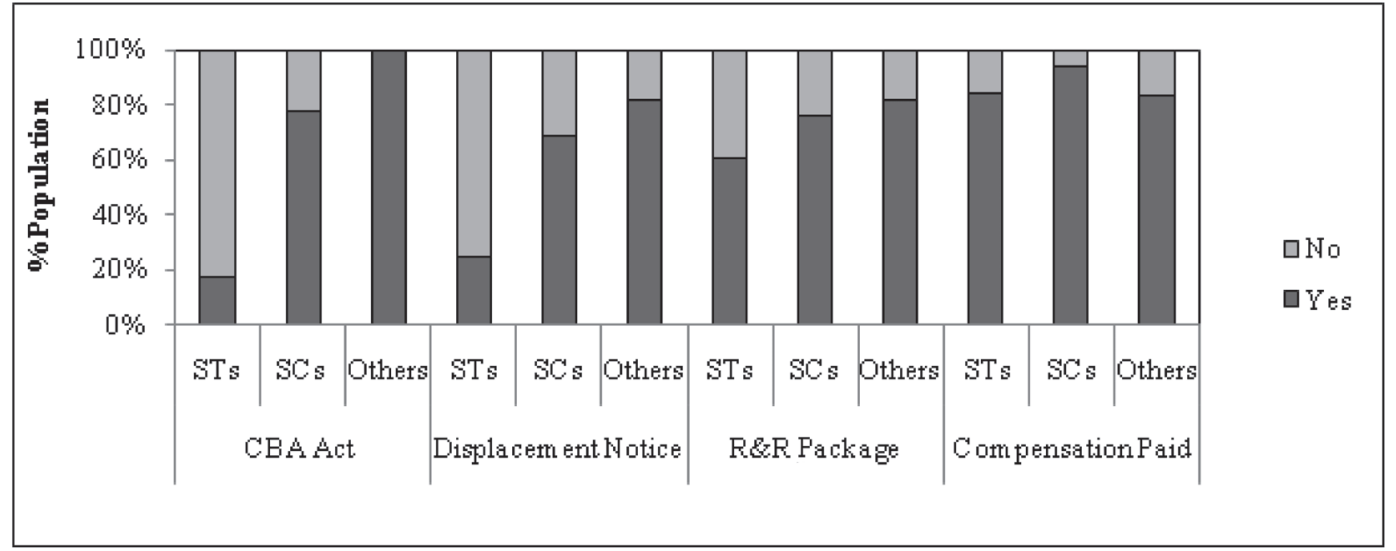

Source: Author's contraction, based on field survey carried out in 2015.

Figure 2 showsthetype of awareness that have been secured by the displaced population from varioussocial groups. Each above-mentioned phenomenon in this sense represents a hierarchy in the level of awareness. The awareness in every respect is very less among the tribals, while far betteramong the others.
The tribals of Sonepur Bazari region were not even aware about the fact that, when do they have to shift on a new location. But as the open cast mines arrived at their courtyard, the $\mathrm{ECL}$ authorities suddenly made them move to a new place with few temporary structures for shelter, insufficient water supply, no toilet facilities and 
above all no other avenues for livelihood. Dispossessed tribals often face these additional problems due to lack of information to them.

Differential Interest among the Dispossessed: The Sonepur Bazari case study shows that the tribal representatives have very little to say either in framing the rules made by the committee to compensate or in the process by which these rules are enforced. It is mainly the influential people among thenon-tribes and tribes who are in a position to be part of the committee; for the mass, they silently go on with the decisionstaken in the meeting with the government officials and local political members. A set of elites always dominates others for their own interests. It is also found that the non-tribal households with landholding always try to shift to the new location very fast, as they can get jobs in mining sector soon. But, this is not true for the tribals and they are caught up in the trap by the act of the dominantgroups.

It is quite evident that, though discussed separately the above-mentioned facts are quite interlinked to each other.

\section{Conclusion}

The impact of mining on the local people of eastern coal mining region of India exemplifies accumulation by dispossession occurring as a result of the new mineral policy made by the government in the age of global capitalism. The essential characteristic of accumulation by dispossession isthe replacement oflong standing traditional forms of production by new marketbased forms of production and consumption. In the Sonepur Bazari mining area, accumulation by dispossession is enacted through the process of relocation and force integration of the tribal as well as peasant population using indirect force and conversion of variousforms of property rights by the weaknesses of Indian lawsand also by the Rand R policies. It also createsa tendency towards polarisation. The adivasi communities of eastern coal mining region of West Bengal haveemerged in their present state of dispossession through stages. The current stage of physical dispossession can be understood as the ultimate stage with a radical change of traditional ways of subsistence level agriculture to non-agricultural informal sector.This is one of the major characteristics of capitalist development.

The experience of dispossession of the tribals and the economically underprivileged sections of the society are more or less identical in the study area. However, the reasons for their deprivation are diverse as well as complex. Very often studies dealing with tribal dispossession seem to overlook the relative socio-economic position in which tribals lived before physical dispossession. Such attempts to bring the entire mass within a single framew ork tend to overlook regional, cultural and class differences existing among the dispossessed. As a matter of fact, the dispossessed is not a homogeneous community, but is confronted with wide range of regional disparities and cultural intricacies, on the one hand, and internal contradictions, on the other.

However,thesocio-economic inequalities across social space are not only confined to the tribes but need to be examined among the nontribals as well. Otherwise, the analysis will remain biased. In thiscontext, the issue of land acquisition, of course, plays an additional role. Considering the issue of land ownership (productive asset and potential income stream), the evidence is right there that class structure has a major role when the issue of dispossession in the Sonepur Bazari region is considered. Tribals are not overall part of the deprived scenario. Apart from experiencing the physical dispossession, they also 
face some additional problems. Studies have clearly demonstrated that tribals are always bypassed in the processof regional development. Considering the fact of development, the landless population in this area is equally deprived like the tribals. Although they aresharing the same physical space with the land owning class, yet find themselves at the peripheries when the issue of land acquisition is considered. On the other hand, the class stratification has also appeared among the tribals as a result of the political economy of capitalist development. Forced integration of tribals in class hierarchy means a loss to tribal identity.

Therefore, the Sonepur Bazari project exemplifies two crucial features of accumulation by dispossession. Harvey describes it as opening up of new fields for accumulation of capital by releasing private and common assets as commodities. It also describes how the capitalists' relationship is contingent upon development strategies of state and transferring the productive resources in the hands of the few while dispossessing the people from their rights. 


\section{References}

1. Agarwal, Bina (1996), "A Field of One's Own: Gender and Land Rights in South Asia," New Delhi, Cambridge University Press.

2. Areeparampil, Mathew (1996), "Displacement Due to Mining in Jharkhand," Economic and Political Weekly,31(24),1524-1528.

3. Asif, Mohammad (2000), "Why Displaced Persons Reject Project Resettlement Colonies," Economic and Political Weekly, 35(24),2005-2008.

4. Banerjee, Sukumar (1981),"Impact of Industrialisation on the Tribal Population of Jharia-Raniganj Coal Field Areas," Calcutta, Anthropological Survey of India.

5. Banerjee-Guha, Swapna (2008),"Space Relations of Capital and Significance of New Economic Enclaves:SEZs in India," Economic and Political Weekly, 51-59.

6. Butler Judith and Athanasiou, Athena (2013), "Dispossession: The Performative in the Political,"Cambridge: Polity Press.

7. Cernea, Michael (1997), "The Risks and Reconstruction Model for Resettling Displaced Populations," World Development, 25(10), 1569-87.

8. Chakravorty, Sanjoy (2013),"The Price of Land:Acquisition Conflict Consequence,"New Delhi:Oxford University Press.

9. Da Costa, Dia (2010), "Development Dramas: Reimagining Rural Political Action in Eastern India," New Delhi, Routledge.

10. Das Gupta, Ranajit (1981),"Structure of the Labour Market in Colonial India," Economic and Political Weekly,16(44/46),pp.1781-1806.

11. Das Gupta, Ranajit (1985), “Migrants in Coal Mines: Peasants or Proletarians, 1850s - 1947," Social Scientist, 13(12), 18 - 43.

12. Dhagamwar, Vasudha (2011), "From Narmada to Nandigram: The Never Ending Clamour for Land as the only Route to Resettlement."

13. Dhagamwar, Vasudha, Subrata De, and Nikhil Verma (2009), "Industrial Development and Displacement: The People of Korba," New Delhi, Sage Publications, India.

14. Fernandes, W. and E.G. Thakural (Eds) (1989), "Development, Displacement and Rehabilitation,”New Delhi, Indian Social Institute.

15. Guha, Abhijeet (2001), "Dispossession of Peasants from Agricultural Land in Medinipur: A Need for Radical Changes in the Policy of the Govt. of West Bengal," Conference on Livelihoods and Poverty Reduction: Lessons from Eastern India.

16. Harvey, David (2009),'The 'New' Imperialism: Accumulation by Dispossession," Socialist Register, 40 (40).

17. Holden, Nadeau and Jacobson (2011), "Exemplifying Accumulation by Dispossession: Mining and Indigenous Peoples in the Philippines," Geograûska Annale B, pp. 141-161. 
18. Kapoor, Dip (2009),"Adivasis (Original Dwellers) in the Way of State-Corporate Development: Development Dispossession and Learning," in Social Action for Land and Forests in India, McGill Journal of Education/Revue des sciences de l'éducation de McGill 44 (1).

19. Kothari, Sumita (1996),"Whose Nation? The Displaced as Victims of Development," Economic and Political Weekly, 31(24), 1476-1485.

20. Lahiri-Dutt, Krishnan and Ahmad (2012), "Land Acquisition and Dispossession: Private Coal Companies in J harkhand, Economic and Political Weekly, 47(6), pp. 39-45.

21. Lahiri-Dutt, Kuntala (1999),"State, Market and the Crisis in Raniganj Coal Belt, Economic and Political Weekly,34(41),pp.2952-2956.

22. $---(-----(2003)$, ,'Informal Coal mining in Eastern India: Evidence from the Raniganj Coalbelt," Natural Resource Forum, 27(1), 68- 77.

23. - - - - - - - (2005), "What Quality of Life in Mining Region,"Economic and Political Weekly, 40(9), pp. 907-908.

24. Levien, Michael (2011), "Special Economic Zones and Accumulation by Dispossession in India," Journal of Agrarian Change, 11(4), 454-483.

25. Mathur, Hari Mohan (Ed) (2013), "Displacement and Resettlement in India: The Human Cost of Development, London/New York, Routledge.

26. Mathur, Hari Mohan (Ed) (2011), "Resettling Displaced People: Policy and Practice in India," New Delhi/ London, Routledge.

27. Meher, Rajkishor (2009), "Globalization, Displacement and the Livelihood Issues of Tribal and Agriculture Dependent Poor People: The Case of Mineral-based Industries in India," Journal of Developing Societies, 25(4), 457-480.

28. Mehta, Lyla(ed.), "Displaced By Development: Confronting Marginalisation and Gender Injustice," New Delhi, Sage Publication, 2009.

29. Mishra, Prajna Paramita (2009),"Coal Mining and Rural Livelihoods: Case of the IB Valley Coalfield, Orissa,"Economic and Political Weekly, 44(44), 117 - 123.

30. Nilsen, Alf Gunvald (2010), “Dispossession and Resistance in India,"London/New York, Routledge.

31. Parasuraman, Saroj (1999), "The Development Dilemma: Displacement in India," Great Britain: Macmillan Press Ltd.

32. Pati, Sushmita (2016),"Accumulation by Possession: The Social Processes of Rent-seeking in Urban Delhi," Eds. Iman Kumar Mitra, Ranabir Samaddar and Samita Sen, Accumulation in Post-Colonial Capitalism, Springer.

33. Pedal, Felix and Samarendra Das (2010),"Out of this Earth: East India Adivasi and the Aluminium Cartel," New Delhi, Orient Blackswan Private Limited.

34. Perreault, Tom (2013),"Dispossession by Accumulation: Mining, Water and the Nature of Enclosure on the Bolivian Altiplano. Antipode 45(5), 1050-1069. 
35. Rothermond, D. and D.C. Wadhwa(eds.), "Zamindars, Mines and Peasants: Studies in the History of an Indian Coalfield," New Delhi, Manohar Publications, 1978.

36. Rothermund, Indira (1978),"The Political Contours of a Coalfield in India,"Asian Survey, 18(6), 560576.

37. Sharma, R.N (2010), "Changing Facets of Involuntary Displacement and Resettlement in India," Social Change, 40(4), 503-524.

38. Shilee, Shubhra (2002),"Indigenous Identity of Tribes in J harkhand," Indian Anthropologist, 32(1\&2), 75-86.

39. Spronk, Susan, and J effery R. Webber (2007), "Struggles Against Accumulation by Dispossession in Bolivia: The Political Economy of Natural Resource Contention," Latin American Perspectives, 34(2), 31-47.

40. Strümpell, Christian (2014),"The Politics of Dispossession in An Odishan Steel Town, Contributions to Indian Sociology, 48(1), 45-72.

41. Vasudevan, Ramaa (2008),"Accumulation by Dispossession in India,Economic and Political Weekly,43(11),41-43.

42. Vasudevan, Vandana (2013), "Urban Villager: Life in an Indian Satellite Town," New Delhi, SAGE Publications India.

43. Whitehead, Judith (2010), "Development and Dispossession in the Narmada Valley,"New Delhi: Pearson Education India. 